\title{
On the Stylistic Features of Massachusetts Constitution
}

\author{
Qingya $\mathrm{Hu}^{\star 1}$ \\ ${ }^{1}$ Wuhan University of Technology, School Of Law, Humanities And Sociology \\ Wuhan, Hubei, China \\ Email: colin.ya@foxmail.com
}

\begin{abstract}
This paper mainly studies the stylistic features of Massachusetts Constitution. Besides, it will start with the linguistic differences between the Constitutions of Massachusetts and U.S.A., further exploring the enlightenment from the stylistic features of Massachusetts Constitution for the translation of Chinese legislative language.
\end{abstract}

Keywords: Massachusetts Constitution, Stylistics, Legislative English, Stylistic Features

\section{INTRODUCTION}

Stylistics, which dates back to ancient rhetoric, comes from Aristotle's rhetoric. The founder of modern stylistics is French stylist Barley. Stylistics is a cross-disciplinary subject that combines literature and linguistics. It is also a branch of applied linguistics [1].

Massachusetts Constitution was one of the earliest constitutions, and the difference between the source of the constitution and the common law source was fully clarified by the adoption of the Massachusetts Constitution. The birth of this constitution marks the emergence of a new concept of "state"[2]. With the establishment of the constitutions of the US states, especially the formulation and implementation of the federal constitution, the United States has since begun a new starting point in its history.

As American law professor Peter M Tiersma [3] wrote in his book Legal Language: "Few professions are as dependent upon language" "Our law is a law of words". Law and language are in a very close relationship. With the Massachusetts Constitution as a carrier, this thesis will study the pure and authentic legal English language, thus revealing the society and culture behind the choice of legal language and providing Chinese legal workers with an understanding of stylistic features and giving reference to English readers. Besides, the research in this thesis is expected to help enrich the application experience of stylistic analysis in the legislative language.

Since China entered the WTO officially, the process of world integration has been expedited, and China has opened the door to the outside world, strengthening its ties with the world. In this process of dialogue with the world, legislative language undoubtedly plays an important role in defending state power. There is no doubt that a correct understanding of the legislative language of both sides is an important prerequisite and guarantee for international cooperation. The Constitution itself has no tangible entity, but the language is the carrier of law. Only through language can the content of the law be reflected.

From the point of view of the whole structure system, language can be divided into three branches: phonetics, vocabulary and grammar, which correspond to each other. For every language, pronunciation represents the material shell of the language, vocabulary represents the combination of the sound and meaning of the language, grammar represents the rule of morphological changes and the rule of sentence-making. And the actual language unit is discourse, which is the whole language formed by a series of consecutive sentences in the process of social communication. English is no exception. Therefore, through the preliminary induction and arrangement of the language features of the Massachusetts Constitution, this thesis reveals the basic rules of its legislative language and provides some useful references for legal research and translators in relevant fields, so that they can accurately and appropriately convey the information contained in the legal text.

\section{LEXICAL FEATURES}

Word is the basic unit of the language system and the most active factor in language. Vocabulary can best reflect linguistic changes, such as the demise of old words, the emergence of new words, and the semantic evolution of existing words [4]. In order to keep up with the pace of social progress, legislative language will change 
constantly to adapt to these changes, which is first manifested at the lexical level.

\subsection{Word length}

As the basic unit of the language system, words have their specific use in different texts. For example, short, individual, and concrete words are usually used at informal or casual situations; and formal or specific occasions require abstract, specific and long words. Due to the unique nature of legal language, legislative language tends to choose long, formal and specific vocabulary. In legislative language, the length of words is the most obvious stylistic feature.

By comparing the results in Table 1, we can find that Massachusetts Constitution is much longer than Constitution of U.S.A. However, our focus is on the average word length. As shown in the table, the average word length of Massachusetts Constitution and Constitution of the U.S.A. is respectively 4.6 letters and 4.8 letters. Obviously, Massachusetts chose longer words in the legislative language, such as expiration, amendment and commissioned. At the same time, the average word length difference between the two constitutions is only 0.2 , which shows that both constitutions tend to use longer words. It means that the word usage in legislative English discourse is very sophisticated, even to the extent of stereotype.

Table 1. The comparison of word length between Constitution of U.S.A. and Constitution of Massachusetts

\begin{tabular}{c|c|c}
\hline Number & $\begin{array}{c}\text { Constitution of U. S. } \\
\text { A. }\end{array}$ & $\begin{array}{c}\text { Constitution of } \\
\text { Massachusetts }\end{array}$ \\
\hline Number of letters & 22743 & 63428 \\
\hline Number of words & 4713 & 12592 \\
\hline Number of sentences & 101 & 478 \\
\hline $\begin{array}{c}\text { Average word length } \\
\text { (lnttor) }\end{array}$ & 4.60 & 4.80 \\
\hline $\begin{array}{c}\text { Average sentence length } \\
\text { (nored) }\end{array}$ & 40.40 & 25.90 \\
\hline $\begin{array}{c}\text { Archaic word } \\
\text { Pronoun }\end{array}$ & 20 & 38 \\
\hline Clause & 210 & 344 \\
\hline
\end{tabular}

\subsection{Archaic words}

Archaic words are rarely used in modern spoken and written English, but they are frequently used in legal English. The tendency of legal English to use archaic words is determined by its own characteristics. First of all, legal English is conservative and inert. The code stresses inheritance and stability. The judge often tends to take the past related case as the reference or the basis. The influence of this situation on the legislative language is that when the legislator makes the law, in order to avoid the ambiguity caused by the change of the original words, a large number of ancient stylistic words are preserved intact. Secondly, legal English is mysterious and authoritative. Legal English is sophisticated in terms, complex in syntax and difficult to understand. This has a profound connection with the legislator's social identity. Because legislators are essentially elites of society, who write obscure words and syntactic complex sentences into the law to reveal their unique elite culture and talent, and to achieve the purpose of legislation to safeguard their class interests and social status.

The most common archaic words in legal English are forms made up of adverbs like 'there, here, where' with one or more prepositions, such as whereon, hereby, herein, hitherto, etc. The use of these archaic words can make the legal style more solemn, accurate, concise and serious. Meanwhile, it is also a unique stylistic feature of legal language.

In the Massachusetts Constitution, there is no shortage of certain archaic words. For example,

And further, full power and authority are hereby given and granted to the said general court... and for the necessary support and defense of the government thereof... [5].(Massachusetts Constitution, Chapter I, Section I, Article IV.)

Table 2. The comparison of archaic words between Constitution of U.S.A. and Constitution of Massachusetts

\begin{tabular}{|c|c|c|c|c|}
\hline Law word & \multicolumn{2}{|c|}{ Constitution of Massachusetts } & \multicolumn{2}{|c|}{ Constitution of U.S.A. } \\
\hline \multirow[t]{2}{*}{ here $^{*}$} & hereby 6 & \multirow{2}{*}{$\begin{array}{c}\operatorname{total}(\mathrm{A}) \\
7\end{array}$} & herein 3 & \multirow{2}{*}{$\begin{array}{c}\text { total }(A) \\
4\end{array}$} \\
\hline & herein 1 & & hereonto 1 & \\
\hline \multirow[t]{6}{*}{ there $^{*}$} & therefore 2 & \multirow{6}{*}{$\begin{array}{c}\text { total }(A) \\
23\end{array}$} & thereby 1 & \multirow{6}{*}{$\begin{array}{c}\operatorname{total}(\mathrm{A}) \\
12\end{array}$} \\
\hline & thereto 2 & & therein 1 & \\
\hline & therein 4 & & thereof 12 & \\
\hline & thereof 13 & & & \\
\hline & thereon 1 & & & \\
\hline & thereupon 1 & & & \\
\hline \multirow[t]{2}{*}{ where $^{*}$} & whereas 5 & \multirow{2}{*}{$\begin{array}{c}\text { total }(A) \\
6\end{array}$} & whereof 2 & \multirow{2}{*}{$\begin{array}{c}\text { total }(\mathrm{A}) \\
1\end{array}$} \\
\hline & whereby 1 & & & \\
\hline \multirow[t]{2}{*}{ what $^{*}$} & whatever 2 & \multirow{2}{*}{$\begin{array}{c}\text { total(A) } \\
2\end{array}$} & whatever 1 & \multirow{2}{*}{$\begin{array}{c}\text { total }(A) \\
3\end{array}$} \\
\hline & & & whatsoever 2 & \\
\hline
\end{tabular}

With reference to Table 2, Constitution of U.S.A. and Massachusetts Constitution used 20 archaic words and 38 archaic words respectively. In Constitution of U.S.A. and Massachusetts Constitution, archaic words accounted for $0.42 \%$ and $0.3 \%$ respectively, which shows that the use of archaic words in the United States Constitution is relatively frequent. As a state constitution, the archaic words used in Massachusetts Constitution are more 
diverse, which includes 11 archaic words, such as hereby, herein, therefore, thereto, and so on. As a result, archaic words in legislative language is a concise and rigorous representative. In the process of legal language translation, classical words should be used to restore the context to form a concise and rigorous style.

\subsection{Pronouns}

Pronouns are parts of speech that replace nouns or sentences. Most pronouns have the functions of nouns and adjectives. Pronouns in English include personal pronouns, subject pronouns, demonstrative pronouns, reflexive pronouns, relational pronouns, interrogative pronouns and so on. Pronouns are used primarily to avoid repetition. However, in complex sentence structures, pronouns often appear at the same time as ambiguity. Therefore, the use of pronouns in legal English should be cautious.

According to Table 3, the proportion of pronouns in Constitution of U.S.A. and Massachusetts Constitution is $4.32 \%$ and $4.46 \%$ respectively. The proportion of the two constitutional pronouns is almost the same.Although the two constitutions are not long, they both use a large number of pronouns. The reader can have a better understanding of the legal provision through the context in a legal English text in which pronouns exist, because the context has implied or explicitly described the referential object. However, readers will inevitably find it difficult to understand the part of the legal text without the relevant context provided. The following sentence gives a good example of this situation.

Table 3. The comparison of pronouns between Constitution of P.R.C. and Constitution of U.S.A. and Constitution of Massachusetts

\begin{tabular}{|c|c|c|c|c|}
\hline \multicolumn{2}{|c|}{$\begin{array}{l}\text { Law } \\
\text { pronoun (N) }\end{array}$} & $\begin{array}{c}\text { Constitution of } \\
\text { P.R.C. }\end{array}$ & $\begin{array}{l}\text { Constitution of } \\
\text { Massachusetts }\end{array}$ & $\begin{array}{c}\text { Constitution of } \\
\text { U.S.A. }\end{array}$ \\
\hline \multirow{11}{*}{$\begin{array}{l}\text { personal } \\
\text { pronoun }\end{array}$} & it & 25 & 41 & 13 \\
\hline & its & 47 & 10 & 8 \\
\hline & itself & 1 & 0 & 0 \\
\hline & he & 0 & 34 & 23 \\
\hline & we & 0 & 1 & 2 \\
\hline & our & 3 & 2 & 3 \\
\hline & ourselves & 0 & 1 & 1 \\
\hline & they & 24 & 30 & 12 \\
\hline & their & 61 & 82 & 20 \\
\hline & them & 2 & 38 & 6 \\
\hline & themselves & 0 & 8 & 1 \\
\hline \multirow{4}{*}{$\begin{array}{l}\text { Demons- } \\
\text { trative } \\
\text { pronoun }\end{array}$} & this & 2 & 85 & 16 \\
\hline & that & 27 & 53 & 16 \\
\hline & these & 2 & 5 & 0 \\
\hline & those & 14 & 11 & 4 \\
\hline relative & what & 0 & 1 & 2 \\
\hline
\end{tabular}

\begin{tabular}{|c|c|c|c|c|}
\hline \multirow[t]{4}{*}{ pronoun } & which & 20 & 37 & 33 \\
\hline & who & 14 & 30 & 9 \\
\hline & whom & 1 & 4 & 2 \\
\hline & whose & 0 & 2 & 1 \\
\hline \multirow{15}{*}{$\begin{array}{l}\text { Indefi- } \\
\text { nite } \\
\text { pronoun }\end{array}$} & all & 1 & 1 & 0 \\
\hline & another & 0 & 1 & 3 \\
\hline & any & 1 & 8 & 2 \\
\hline & anyone & 0 & 0 & 0 \\
\hline & anything & 0 & 0 & 2 \\
\hline & both & 0 & 2 & 4 \\
\hline & each & 3 & 3 & 3 \\
\hline & either & 0 & 7 & 5 \\
\hline & everyone & 0 & 0 & 0 \\
\hline & neither & 0 & 0 & 3 \\
\hline & nothing & 0 & 1 & 1 \\
\hline & one & 6 & 4 & 4 \\
\hline & (the) said & 0 & 6 & 3 \\
\hline & same & 6 & 35 & 8 \\
\hline & such & 2 & 1 & 0 \\
\hline \multicolumn{2}{|c|}{ Total $(\mathrm{N})$} & 262 & 544 & 210 \\
\hline \multicolumn{2}{|c|}{ Proportion } & $2.5 \%$ & $4.32 \%$ & $4.46 \%$ \\
\hline
\end{tabular}

The enacting style, in making and passing all acts, statutes and laws, shall be -- "Be it enacted by the Senate and House of Representatives in General Court assembled, and by the authority of the same [5]." Massachusetts Constitution, Chapter VI, Article VIII)

Based on this situation, many legal workers believe that pronouns should be used as little as possible in legislative language to avoid ambiguity caused by highfrequency pronouns, although this often comes at the expense of simplicity.

\subsection{Shall}

The frequent use of modal verbs is another important feature of legal English which is different from ordinary English. Many laws and regulations, contracts and legal documents in legal English are accomplished by the use of modal verbs. In legal English, modal verbs are used to express legal authorizations, compulsions and prohibitions. In the legal provisions, the modal verb "shall" means "the responsibility and obligation to be borne", usually expressing the specific provisions and requirements, which are prescriptive and mandatory, and are not just a kind of tense. In other words, shall means that obligations that must be performed under laws, decrees, regulations, etc., are often used for third-person purposes and do not imply a future. The examples followed will give a good demonstration.

All writs issuing out of the clerk's office in any of the courts of law, shall be in the name of the Commonwealth of Massachusetts: they shall be under the seal of the court from whence they issue: they shall bear test of the first justice of the court to which they shall be returnable, who 
is not a party, and be signed by the clerk of such court [5]. (Massachusetts Constitution, Chapter VI, Article V.)

There are 312 "shall" in Massachusetts Constitution and 190 "shall" in Constitution of U.S.A., accounting for $2.47 \%$ and $4.03 \%$ of the full-text words respectively. Obviously, compared with the federal constitution, the use of "shall" is reduced in Massachusetts Constitution. It shows that the Constitution of U.S.A. has the highest authority, and the implementation of the Massachusetts Constitution must be authorized by the Federal Constitution.

\section{SYNTACTICAL FEATURES}

Syntax is the study of the rules governing the ways words, word groups and phrases are combined to form sentences in a language, or the study of the interrelationships between elements in sentence structures [6]. In the research of legal English translation, people will find that constitutional documents are difficult to understand and difficult to convert, mainly due to the characteristics of the legislative language. The most representative syntactical features of legislative English are discussed here. It covers three aspects: phrase, clause, and sentence.

\subsection{Clause}

Clauses often play a modifying role in English. It connects modifiers and modified objects, making them more closely connected. In legal English, the use of clauses enables readers to realize the accuracy and complexity of legislative language. There are various relative clauses in English, which include who-clause, where-clause, what-clause, when-clause, if-clause and so on. The application of these clauses in legal English has its unique effect.

Table 1 clearly shows the difference in the use of clauses between the Constitution of U.S.A. and the Massachusetts Constitution, which uses 75 clauses and 36 clauses respectively. From the point of view of data, Massachusetts Constitution has far less use of clauses than the Constitution of U.S.A. But there are still many classic clauses, for example,

In all cases where sums of money are mentioned in this constitution, the value thereof shall be computed in silver at six shillings and eight pence per ounce... [5].(Massachusetts Constitution, Chapter VI, Article III.)

\subsection{Sentence}

Sentence length is another important stylistic marker. The average sentence length of legal English is much longer than that of ordinary English. According to statistics, the average sentence length of Massachusetts Constitution is 25.9 words.
According to the date in Table 1, the average sentence length of Massachusetts Constitution and Constitution of U.S.A. is 25.9 words and 40.4 words respectively. The former is significantly less than the latter by 14.5 words. These figures suggest that the legislative language in Massachusetts Constitution is simpler than Constitution of U.S.A. From a sentence-length point of view, it is still longer than the average level (17 words) of ordinary English. Even so, it still represents the unique style of the legislative language in English-speaking countries.

There are two kinds of voice in English: active voice and passive voice, which respectively indicate whether the subject of the sentence is the executor or receiver of the action. Unlike the active voice advocated by modern Plain English, the appearance of passive voice in legal English is more frequent. The former pays attention to the conciseness, directness and nature of sentences. However, the coherent use of passive voice helps to produce a formal effect, which is more objective. Therefore, the passive voice gives the reader an objective and authoritative atmosphere. This effect is also beneficial to the enforcement of the law, which conveys a message that has nothing to do with personal bias. There are many passive voices in the Massachusetts Constitution. For example,

And no person shall ever be admitted to hold a seat in the legislature... [5]. ( Massachusetts Constitution, Chapter VI, Article II)

In all cases where sums of money are mentioned in this constitution, the value thereof shall be computed in silver at six shillings and eight pence per ounce... [5].(Massachusetts Constitution, Chapter VI, Article III.)

In sentence 1, "hold a seat" appears in the second half of the sentence and shall be the focus of this Law. The second sentence clearly means calculating in silver. The above examples show that passive voice is more flexible than active voice and is more suitable for various purposes or priorities.

\section{TEXTUAL FEATURES}

In stylistic research, a very important macro-level of research is discourse. The present research on it mainly concentrates on the cohesion and coherence in the text. Coherence is one of the distinctive features of any text. According to Halliday and Hasan [7], cohesion is achieved through four devices: reference, ellipsis, conjunction and lexical organization. We will discuss hereafter.

\subsection{Ellipsis}

The use of pronouns in legislative languages has been discussed above. Ellipsis is used similarly to pronouns in order to avoid repetition. The omitted object can be a word or a group of meanings, or a clause. At the 
grammatical and semantic levels, ellipsis help avoids duplication and link context closely. However, the ellipsis in legal language is very rare because of the authority and seriousness of legislative language. Ellipsis often occurs in informal situations or oral situations, and it is inconsistent with the stylistic features of legislative language. Therefore, the occurrence of ellipsis should be avoided in legal English. Instead, pronouns are used more frequently. In many cases, legal language would rather use pronouns than ellipsis to avoid repetition. Through retrieval, there is no ellipsis in the Massachusetts Constitution. In most cases, pronouns are still used to achieve the same effect. For example:

In the government of this commonwealth, the legislative department shall never exercise the executive and judicial powers, or either of them: the executive shall never exercise the legislative and judicial powers, or either of them: the judicial shall never exercise the legislative and executive powers, or either of them: to the end it may be a government of laws and not of men [5].(Massachusetts Constitution, Part The First, Article XXX.)

In this example, "the executive and judicial powers" is replaced by "them", and "it" refers to the legislative department. Without ellipsis, the readability of the text has been guaranteed.

\subsection{Conjunction}

The term, conjunction, is used to join together words, groups, or clause. In English, there are coordinating conjunctions such as 'and' and 'but', and subordinating conjunctions such as 'although', 'because' and 'when' . Conjunctions, as a recognized logical maker, are essential to legal English. Conjunction often realizes the close cohesion of intra-text logic by syntactic means and grammatical means. Here are some of the sentences in the Massachusetts Constitution as examples.

Example of "and" for addition:

The people of this commonwealth have the sole and exclusive right of governing themselves, as a free, sovereign, and independent state; and do, and forever hereafter shall, exercise and enjoy every power, jurisdiction, and right, which is not, or may not hereafter, be by them expressly delegated to the United States of America in Congress assembled. [5].(Massachusetts Constitution, Article IV)

\subsection{Lexical cohesion}

As an important cohesive device in legal language, lexical cohesion usually takes reiteration as the main form. Cohesive effects can be achieved by synonyms, or repetition of the same word. Let's look at the example of lexical cohesion in the Massachusetts Constitution.
And whereas there have been at sundry times, by divers persons, gifts, grants, devises of houses, lands, tenements, goods, chattels, legacies and conveyances, heretofore made, either to Harvard College in Cambridge, in New England, or to the president and fellows of Harvard College, or to the said college, by some other description, under several charters successively[5]...(Massachusetts Constitution, Chapter V, Article II )

And whereas, by an act of the general court of the colony of Massachusetts Bay passed in the year one thousand six hundred and forty-two, the governor and deputy-governor, for the time being, and all the magistrates of that jurisdiction [5]....(Massachusetts Constitution, Chapter V, Article III)

In this example, we can see that the same structure "And whereas" appears repeatedly and orderly. This phenomenon is naturally regarded as verbatim in modern Plain English. However, in legal English, this kind of repetition which is similar to a parallel structure, provides better readability and also gives readers a good visual experience. Through this repetitive structure, the reader may spontaneously link these laws and regulations and understand them. In this way, it will contribute to the good popularization and enforcement of the law. Based on this fact, legal English needs to be expressed in such a way.

\section{CONCLUSION}

With the process of internationalization, legislative English is quite necessary for the publicity of China's legal system and crucial in showing the strength of the social legal system with Chinese characteristics to the world. Although the Massachusetts Constitution is only a microcosm of the United States federal constitution, we can still have a glimpse of it, by studying its stylistic features, to get a useful reference for the study and publication of Chinese legal English.

Guided by the stylistics theory, this thesis examines the Massachusetts Constitution from the perspectives of lexical, syntactical and textual features and makes analysis on its words, sentences and text.

The systematic comparison shows clearly the differences in legislative English between the federal constitution and the Massachusetts Constitution, thus further exploring the significant stylistic features of the Massachusetts constitution. At the lexical level, the Massachusetts Constitution has such features: (1) the average word length is longer and the words used are elegant; (2) archaic words and pronouns are more frequently used; (3) sentence including the special verb "shall" is relatively simple. These characteristics are determined by their formality and solemnity. Therefore, in the process of translation, the translator should intentionally use some formal words and expressions 
instead of personal pronouns, so as to realize accurate expression, avoid ambiguity in understanding and embody the majesty of laws and regulations. At the syntactic level, Massachusetts Constitution has the following features: (1) fewer clauses are expressed; (2) there is a shorter length of sentence and more natural word order; (3) passive voice is commonly used. These characteristics are determined by the accuracy and conciseness of legislative texts. The enlightenment to Chinese translators lies in the skillful use of passive voice to emphasize the purpose and the concise cohesion of sentences. At the textual level of Massachusetts Constitution: (1) omission is extremely rare; (2) cohesion is widely used. According to the above characteristics, we realize that translators should fully consider these terminological norms and characteristics of the legislative language of the target language in the process of translation, so as to ensure that the accuracy, authority, and seriousness of the law will not be affected.

\section{REFERENCES}

[1] Wright, L., Hope J. (2000) Stylistics: A Practical Coursebook. Foreign Language Teaching and Research Press. Shanghai.

[2] Li J. (2004) The Significance and Influence of the Massachusetts Constitutional Movement during the American Revolution. Historical Research, 1: 130-144.

[3] Tiersma, P. M. (1999) Legal Language. The University of Chicago Press. Chicago.

[4] Thomas, C. (1993) A Companion to Baugh and Cable's History of the English Language. Routledge Press. London.

[5] United States House of Representatives. (1995) The Constitution of Massachusetts http://www.house.gov/Constitution/Constitution.ht $\mathrm{ml}$.

[6] Hu Z. (1994) Discourse Cohesion and Coherence. Shanghai Foreign Language Education Press. Shanghai.

[7] Halliday, M. A. K., Hason R. (1976) Cohesion in English. Longman Group Limited. London. 